\title{
Risking one's Life to Petition the Authorities: The black jail industry in China
}

\section{Hugo Winckler}

Translator. Will Thornely

\section{OpenEdition \\ Journals}

\section{Electronic version}

URL: http://journals.openedition.org/chinaperspectives/6330

DOI: 10.4000/chinaperspectives.6330

ISSN: 1996-4617

\section{Publisher}

Centre d'étude français sur la Chine contemporaine

\section{Printed version}

Date of publication: 1 December 2013

Number of pages: $76-77$

ISSN: 2070-3449

\section{Electronic reference}

Hugo Winckler, "Risking one's Life to Petition the Authorities: The black jail industry in China », China Perspectives [Online], 2013/4 | 2013, Online since 01 December 2013, connection on 15 September 2020. URL : http://journals.openedition.org/chinaperspectives/6330 
like people to believe it is, and Taiwanese publishers have never succeeded in exploiting the common language that unites them with the mainland. They have always come up against barriers put in place by the Chinese authorities, and which the agreement has only partially lifted. ${ }^{(5)}$ The opening did not take place based on a spirit of reciprocity, and the future of Taiwanese publishing is not to be found on the other side of the strait, but lies in its internationalisation, in particular through making the most of the digital revolution. It is with this aim in mind that Hao Ming-Yi says he turned to New
York in 2012. In other words, Hao Ming-Yi is calling on his compatriots to free themselves of the blinkers of Chinese "tropism" hampering MaYing-Jeou and his entourage, who are unable to see beyond Taiwan-China relations.

\section{Translated by Will Thornely.}

5. For more on this subject, see "Publishing Industry Laments 'Unfair' Pact," Taipei Times, 15 July 2013.

\section{Risking one's Life to Petition the}

\section{Authorities: The black jail industry in China}

\section{Analysis by Hugo Winckler based on the following sources:}

- Xin Shengzhi, (1) “全国政协提出建立健全非正常上访终结机制” (The Chinese People's Political Consultative Conference proposes the establishment of a robust system for resolving unauthorised petitions), Nanfang Dushi Bao - Southern Metropolitan Weekly, 4 March 2013.

- Liu Xiangang, (2) “非正常上访终结机制: 法治还是反法治” (Does the mechanism for resolving unauthorised petitions run contrary to the workings of a constitutional state?), Gongshi Wang, 4 March 2013.

- Tian Cheng, (3) “河南截访干部参股黑保安公司” (The officers responsible for intercepting the petitioners from Henan had shares in an illegal public security company), Nanfang Zhoumo - Southern Weekend, 22 February 2013.

n order to pave the way for the reporting of complaints from civil society, China has set up the "Bureau of Letters and Calls" system (信访局 xinfangju). Chinese citizens can bring disputes they are having with the public authorities to be heard by this institution, and cases may even be heard in Beijing at the National Bureau of Letters and Calls, where hundreds of petitioners from all over the country present their grievances on a daily basis. It is clearly a complex situation, because the comings and goings of unhappy petitioners - often in a procession - creates a risk to social stability. This being the case, ingenious entrepreneurs have developed an illegal industry that involves intercepting the petitioners. One recent case saw the sentencing of a number of criminals who were found guilty of having set up illegal practices concerning these activities. Press articles commenting on the case help provide an understanding as to how this new economic activity operates.

\section{Unauthorised petitions}

The Chinese government classifies the petitions it receives into two separate categories: "authorised petitions" (正常上访 zhengchang shangfang) and "unauthorised petitions" (非正常上访 feizhengchang shangfang), the first being allowed by law while the second are not. DiYingqi, (4) law professor at the Henan University of Finance, Economics, and Law, explains that local governments have identified three types of unauthorised petitions, which are described as "disturbing, disruptive, or illegal" 缠访、闹访、非法 上访 chanfang, naofang, feifa shangfang). Yet none of these descriptions meets specific legal criteria, creating a vagueness that gives the government a great deal of discretionary power. Consequently, the public authorities can contest the legitimacy of a petition, and there is no legal route of appeal against the administrative decision reached. However, as Di Yingqi notes, the right of petition is important to the development of China, and should, on the contrary, be subject to increased protection. What makes this discretionary power more dangerous still is the fact that unauthorised petitions are, in certain cases, punishable by re-education through labour. ${ }^{(5)}$

\section{The Wang Gaowei case}

The Wang Gaowei case recently caused much ink to flow in China, because it shed light on the practices of an illegal industry linked to the petitioning system. As Tian Cheng reported in Nanfang Zhoumo, Wang Gaowei, a peasant originally from Henan Province, opened a services company in Beijing whose business was to apprehend petitioners from his province of origin. The Beijing police broke up his network in December 2012, and Wang and his accomplices were handed prison terms in March 2013.

According to Tian Cheng, Wang Gaowei had entered into business with Bai Rongxing, an official from the Bureau of Letters and Calls of his city, who had been sent to Beijing by his employers to stop petitioners there. The trial of Wang and Bai produced a great deal of commentary, and offers unique insight into the operation of this activity, with its quite distinctive Chinese flavour.

Examining the workings of this company in greater detail, Tian Chen reports on the existence of an official document held by Wang Gaowei, which explained the procedure to follow in the event of "unauthorised and dis-

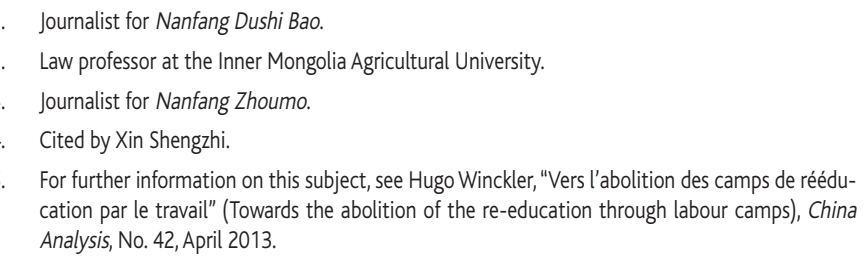

. For further information on this subject, see Hugo Winckler, "Vers l'abolition des camps de rééducation par le travail" (Towards the abolition of the re-education through labour camps), China Analysis, No. 42, April 2013 
ruptive petitions in Beijing." This text, which dates back to 2008 and was produced by the public authorities of the Xuchang Shi ${ }^{(6)}$ prefecture (许昌市), stipulates that such petitions should be dealt with "first with a warning, then custody, and finally re-education through labour." However, it also states that if the petitioner turns to the foreign media or expresses his discontent on social media networks, he can be directly subject to administrative detention or sentenced to re-education through labour.

\section{Black jails}

The work of intercepting and detaining petitioners on their way to Beijing is rarely carried out by police officers, and is usually the result of entrepreneurial activity. Preventative private companies set up and manage "illegal prisons" (黑监狱 hei jianyu), in which individuals considered a threat to social stability are held outside any legal procedure. These illegal prisons are managed, as noted by Tian Cheng, by private companies nicknamed "illegal public security companies" (黑保安公司 heibaoan gongsi). Such companies intercept, detain, and send petitioners back to their city or region of origin in exchange for commission paid by the local government.

Tian Cheng, drawing on Wang Gaowei's trial for some of his information, reports that there is often a system of cooperation between the public security companies and the local authorities of the Party. The author cites the academic Yu Jianrong, who has identified the existence of two models: either the local government advances the social capital required to create an independent company and funds it, or it sends agents to Beijing to directly become stakeholders in the public security company. The local civil servant, who is often an employee of the Bureau of Letters and Calls, moves to Beijing, where he pursues petitioners from his city. According to the journalist, local governments pay 200 to 300 yuan (14 to 21 euros) per person per night in detention, and this represents the main source of income of these illegal public security companies. He claims that the annual budget of the public administration for the interception of petitioners was, for example, 100,000 yuan for Wang Gaowei's city of origin, Yuzhou (禹州, Henan Province) alone.

Yu Jianrong writes that the growth in the use of illegal prisons answers a double need. On the one hand, local officials need to maintain a certain degree of stability; indeed, they risk losing their position if they are not able to control the flow of petitioners going to the capital. On the other hand, it is a highly lucrative activity. Tian Cheng claims that, in the case of Wang Gaowei and Bai Rongxing, what started as the local government's wish to provide stability, and saw them send an official to Beijing in order to perform this function, grew into a full-scale money-making venture for Wang and Bai.

Bai Rongxing arrived in Beijing for the first time in 2010, having been posted there to pursue petitioners originating from Henan. At the time, he was officially registered as an official working for the Bureau of Letters and Calls in the city of Yuzhou. However, Wang and Bai quickly developed the field of activity of their company, proposing their services to Yuzhou's neighbouring cities. As the journalist points out, the prospects in terms of profits were great enough to make the possibility of legal proceedings against them a risk worth taking.

However, this precarious and illegal system of intercepting petitioners has recently shown its limits, and the central government has expressed its wish to reform the institution in order to establish a robust legal mechanism for resolving unauthorised petitions.

\section{Political projects to reform the petitioning system}

The petitioning system has been undergoing a process of continuous reform ever since it was created. The underlying intention remains the same: to deal with the endemic problem of the impact of protest movements on social stability. The arrival in the capital of processions of petitioners or combative individual petitioners who persistently appeal to the system to obtain redress for a wrong done to them is seen by the political powers as a major risk to social stability. As noted by Liu Xiangang, the increasingly violent and dissenting nature of the protests has made reform necessary.

Xin Shengzhi reports that in March 2013, at the $11^{\text {th }}$ session of the Standing Committee of the National People's Congress, Jia Qinglin, a member of the Politburo, confirmed the wish of the public authorities to put in place a robust system for resolving illegal petitions. As the journalist notes, this reform project is not new. A review committee, which carried out inquiries in various provinces, drew up a report back in 2009, which was followed by another in 2012. The journalist sets out the main steps of the reform to the system. In 2005, a ruling by the Central Bureau of Legal and Political Affairs on the procedure to follow in order to resolve petitions states that it is possible, after having petitioned the Party at the local level, to have the claim heard at a second and then third level (city, province, then the National Bureau in Beijing). However, once these three levels have been exhausted, the claim can be taken no further. Nevertheless, these directives are not sufficient when it comes to preventing the most determined petitioners from continuing to express their grievances. The journalist also states that the public authorities have improved the quality of hearings, making them public and forcing the authorities to launch inquiries immediately in order to better satisfy the claimants.

\section{A reform that goes against the advance of the rule of law?}

The new reform project, which was started in March 2013, has already been the subject of criticism, as Liu Xiangang's article details, asking whether or not this reform complies with the rule of law. The author sums up the proposition as follows: if the petitioner maintains his challenge, the high court concerned hears the accounts of all parties concerned in the case, and comes to a definitive conclusion. The author expresses the idea that although the reform starts off with the right intentions, it runs in the opposite direction to that required to improve the rule of law, and represents a return to authoritarianism. He reasons that such a procedure does not give claimants any of the basic protections a constitutional state is required to provide. Instead, the judge takes an authoritarian decision without the instigation of legal proceedings in which the rights of the parties are guaranteed by robust procedural rules.

Liu Xiangang argues that for this reason, the reform should move towards a normalisation of the legal procedure and attempt to bring as many claims as possible into the area of competence of the courts of justice. The author highlights all the contradictions and weaknesses of the Chinese model, which attempts to improve the procedures for resolving disagreements without truly knowing in which direction to go.

\section{Translated by Will Thornely.}

6. A prefecture-level city in Henan Province, whose jurisdiction covers the city of Yuzhou. 